\title{
Hoe staan urologische zorgverleners en huisartsen tegenover het gebruik van een moleculaire biomarkertest voor prostaatkanker in de huisartsenpraktijk?
}

\author{
Karine Wendrich (D) - Lotte Krabbenborg
}

Geaccepteerd op: 14 april 2021 / Published online: 3 mei 2021

(C) The Author(s) 2021

\begin{abstract}
Samenvatting Moleculaire biomarkertests die momenteel hun intrede doen binnen de urologie zouden wellicht kunnen bijdragen aan het terugdringen van de huidige overdiagnostiek en overbehandeling van prostaatkanker. Deze tests zouden eventueel ook toegepast kunnen worden in de huisartsenpraktijk, om onnodige doorverwijzingen naar de uroloog te voorkomen. Om beter inzicht te krijgen in bevorderende en belemmerende factoren voor de acceptatie van nieuwe moleculaire biomarkertests voor prostaatkanker in de huisartsenzorg, zijn 20 urologische zorgverleners en 12 huisartsen geïnterviewd, waarbij de focus op de SelectMDx-test lag. De geïnterviewde zorgverleners erkenden de mogelijke voordelen van deze tests. Er waren echter ook twijfels, bijvoorbeeld ten aanzien van meerwaarde en praktische haalbaarheid. Ook is het niet vanzelfsprekend dat er draagvlak onder huisartsen en urologen is om deze biomarkertests in de huisartsenpraktijk toe te gaan passen. Dit artikel sluit af met enkele overwegingen rond een betere afstemming tussen de ontwikkeling van biomarkertests enerzijds en de wensen en behoeften van zorgverleners anderzijds.
\end{abstract}

Trefwoorden prostaatkanker - moleculaire biomarkertests $\cdot$ huisartsenpraktijk · acceptatie van technologie

\section{How do urological healthcare providers and general practitioners view the use of a molecular biomarker test for prostate cancer in general practice?}

Abstract Novel molecular biomarker tests that are already being used in urological practice might contribute to reducing the current overdiagnosis and overtreatment of prostate cancer. Maybe these tests could also be applied in general practice, to prevent unnecessary referrals of men to secondary care. In order to gain insight into enabling and constraining factors for the acceptance of novel molecular biomarker tests for prostate cancer in general practice, twenty urological healthcare providers and twelve general practitioners have been interviewed, with a focus on the SelectMDx test. The interviewed healthcare providers acknowledged the potential value of these tests However, also doubts have been expressed, for instance regarding the added value and feasibility. Moreover, it is not self-evident that general practitioners and urologists support the application of these biomarker tests in general practice. This article concludes with some considerations to better align the development of biomarker tests on the one hand with the needs and desires of healthcare providers on the other hand.

Keywords prostate cancer - molecular biomarker tests $\cdot$ general practice $\cdot$ technology acceptance

\section{Introductie}

K. Wendrich, MSc · L. Krabbenborg, PhD ( $ه)$

Institute for Science in Society, Radboud Universiteit

Nijmegen, Nijmegen, Nederland

lotte.krabbenborg@ru.nl

K. Wendrich, MSc

Karine.Wendrich@ru.nl
Zowel binnen de urologie als de huisartsenzorg bestaan zorgen over de vraag of routinematig toepassen van de prostate specific antigen (PSA) test leidt tot overdiagnose en overbehandeling van prostaatkanker. Daarom is er behoefte aan methoden om een betere 


\title{
Hier staat een advertentie.
}

\author{
$c$ bohn

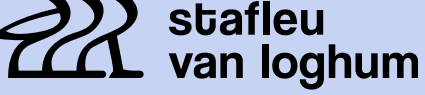 \\ Springer Media
}

Houten 2021 


\title{
Hier staat een advertentie.
}

\author{
$c$ bohn

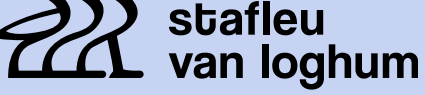 \\ Springer Media
}

Houten 2021 


\section{Uitslag:}

De SelectMDx uitslag voor deze patiënt geeft een waarschijnlijkheid van $88 \%$ op prostaatkanker in prostaatbiopten. Daarbij bedraagt de kans op een Gleason score $\geq 7$ tumor $63 \%$. Hierbij wordt uitgegaan van een standaard biopsie procedure, d.w.z. 12 echogeleide prostaatbiopten.
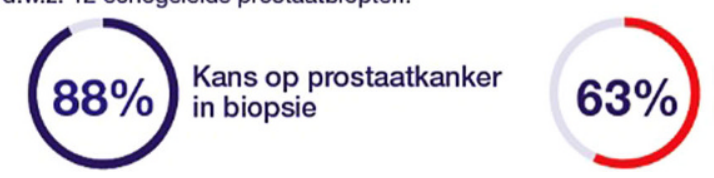

Kans op Gleason score $\geq 7$

prostaatkanker in biopsie

Figuur 1 Voorbeeld van een uitslag van de SelectMDx-test met links de kans dat bij biopsie prostaatkanker gevonden zal worden en rechts de kans dat er bij die biopsie agressieve prostaatkanker (Gleason-score $>7$ ) gevonden zal worden

risicostratificatie te kunnen maken bij de vroege opsporing van prostaatkanker, waarbij zowel de prostaatkankermortaliteit als overdiagnose en overbehandeling zo veel mogelijk worden gereduceerd. Nieuwe technologieën, zoals risicopredictiemodellen en magnetic resonance imaging (MRI) kunnen hierbij helpen [1]. Ook zijn er de afgelopen jaren verschillende moleculaire biomarkertests voor prostaatkanker op de markt verschenen. Deze tests maken veelal gebruik van bloed- of urinemonsters en bieden een risicostratificatie van welke mannen een klinisch-significante vorm van prostaatkanker hebben [2-4].

Binnen de Nederlandse urologie wordt al beperkt gebruikgemaakt van dit soort moleculaire biomarkertests, met name van de SelectMDx-test (MDxHealth, Irvine, CA). Deze test bepaalt het risico dat er klinisch significante prostaatkanker, oftewel een Gleason-score $\geq 7$, wordt aangetroffen in prostaatbiopten en vormt daarmee een hulpmiddel in de klinische besluitvorming over het al dan niet overgaan tot biopsie bij mannen met een licht verhoogde PSA-waarde. De risicoscore, die uitgedrukt wordt in een percentage (fig. 1), is gebaseerd op de expressie van twee mRNAbiomarkers (HOXC6 and DLX1) in de urine na uitvoering van een prostaatmassage, gecombineerd met klinische parameters zoals PSA-niveau, prostaatvolume en leeftijd [5-7]. Studies naar de validiteit en kosteneffectiviteit van de SelectMDx-test in de tweede lijn laten veelbelovende resultaten zien [5-9]. Ons eerdere onderzoek naar het gebruik van de SelectMDxtest binnen de Nederlandse urologie heeft echter laten zien dat het niet vanzelfsprekend is dat zorgverleners gebruikmaken van moleculaire biomarkertests voor prostaatkanker [10]. Zo uiten urologen twijfels over de klinische betrouwbaarheid van de SelectMDxtest en de meerwaarde ten opzichte van risicopredictiemodellen en MRI.

MDxHealth, het bedrijf dat de SelectMDx-test ontwikkelt, heeft plannen om op termijn deze test ook beschikbaar te stellen voor de huisartsenpraktijk. De uitslag van een moleculaire biomarkertest bij mannen met een licht verhoogde PSA-waarde en een niet afwijkend rectaal toucher zou de doorslag kunnen geven bij de beslissing om door te verwijzen naar de tweede lijn voor biopten of een MRI, of, bij een zeer laag risico op klinisch-significante prostaatkanker, juist niet, en in zo'n geval alleen de PSA-waarden te volgen. Toe- passen van een moleculaire biomarkertest in de huisartsenpraktijk zou onnodige doorverwijzingen naar de tweede lijn kunnen voorkomen, wat zou kunnen resulteren in een kostenreductie en ontlasting van de urologische zorg.

$\mathrm{Er}$ is nog geen wetenschappelijk onderzoek gedaan naar de validiteit en effectiviteit van de SelectMDxtest, of andere moleculaire biomarkertests voor prostaatkanker, binnen de huisartsenzorg. Echter, ook als de wetenschappelijke onderbouwing er wel komt, is het niet vanzelfsprekend dat huisartsen en urologen op deze test zitten te wachten. Het is namelijk bekend dat de implementatie van innovaties in de zorg een langdurig en complex proces is. Dit proces wordt beïnvloed door een dynamisch samenspel tussen technische, sociale en institutionele factoren, zoals in hoeverre zorgverleners de waarde van de innovatie inzien, of er mogelijkheden zijn om de dagelijkse werkpraktijk aan te passen, en of er sprake is van financiële vergoeding [11-13]. Om de landing van innovaties in de zorgpraktijk te faciliteren, is het daarom van belang om al in een vroeg stadium mogelijke knelpunten en dilemma's op te sporen, zodat deze uiteindelijk meegenomen kunnen worden bij het ontwikkelen van implementatiestrategieën [14, 15].

Dit kwalitatieve onderzoek is opgezet om de verwachtingen, wensen en zorgen van zowel urologische zorgverleners als huisartsen in kaart te brengen omtrent het gebruik van moleculaire biomarkertests voor prostaatkanker in de huisartsenpraktijk. We hebben ervoor gekozen om de SelectMDx-test als concreet voorbeeld te gebruiken. Deze test wordt op dit moment het meest gebruikt door Nederlandse urologen. Op deze manier konden wij, ondanks de hypothetische situatie, zo concreet mogelijk worden in onze interviews.

\section{Materiaal}

\section{Dataverzameling urologische zorgverleners}

Tussen juli 2018 en mei 2019 zijn 20 urologische zorgverleners geïnterviewd, onder wie 16 urologen en vier verpleegkundig specialisten. Contacten zijn verkregen via de salesafdeling van MDxHealth, het bedrijf achter de SelectMDx-test, en op suggestie van andere respondenten. De interviews duurden tussen de 
20 en 70 minuten (gem. $40 \mathrm{~min}$ ). In de interviews zijn de urologische zorgverleners bevraagd over hun persoonlijke ervaringen met de SelectMDx-test en wat zij als redenen zagen om deze test wel of niet te gebruiken (het primaire doel van de interviews; zie een eerder artikel [10]). Ook is de mogelijke implementatie van de SelectMDx-test in de huisartsenpraktijk besproken. Vragen betroffen wat zij vonden van die implementatie en wat voor kansen en uitdagingen ze hierbij zagen. Omdat de interviews met urologische zorgverleners meerdere thema's bevatten, trad er na 20 interviews thematische verzadiging op.

\section{Dataverzameling huisartsen}

Tussen februari 2019 en mei 2019 zijn 12 huisartsen geïnterviewd. Huisartsen werden doelgericht benaderd om respondenten te rekruteren met een zo groot mogelijke rijkdom aan informatie. Dit waren bijvoorbeeld huisartsen met een sterkere affiniteit met prostaatkanker dan de gemiddelde huisarts. Ook werden er huisartsen benaderd met een bestuursfunctie bij een landelijke of regionale huisartsenvereniging. Door deze functie hebben deze huisartsen goed zicht op het reilen en zeilen van de huisartsenwereld. Zes van de geïnterviewde huisartsen waren ten tijde van het interview werkzaam in de regio Nijmegen, de rest werkte verspreid over het land. De interviews duurden tussen de 15 en 70 minuten, met een gemiddelde duur van
45 minuten. Voorafgaand aan de interviews hadden de huisartsen per e-mail een informatiebrochure en een voorbeeld van een uitslagformulier van de SelectMDx-test ontvangen, zodat ze een beter beeld kregen van hoe een dergelijke biomarkertest in zijn werk gaat. Gedurende de interviews werden huisartsen bevraagd over de mogelijke voor- en nadelen die zij zien van dit soort moleculaire biomarkertests voor prostaatkanker in hun praktijk en onder welke voorwaarden zij dergelijke tests zouden willen gebruiken. In de interviews met huisartsen trad na 12 interviews thematische verzadiging op.

\section{Data-analyse}

Zowel voor de interviews met urologische zorgverleners als de interviews met huisartsen werd de dataverzameling gestopt zodra er geen nieuwe thema's meer naar boven kwamen tijdens de interviews en datasaturatie was bereikt. Alle interviews zijn opgenomen en uitgeschreven na toestemming van de respondenten. De transcripten zijn geüpload in het kwalitatieve data-analyseprogramma 'Atlas.ti 8'. De interviews met urologische zorgverleners en met huisartsen zijn afzonderlijk van elkaar geanalyseerd. Wel zijn voor de analyse van alle interviews dezelfde stappen doorlopen, waarbij gebruik is gemaakt van inductieve analyse [16]. De eerste stap was het identificeren van voorlopige codes door het herhaaldelijk lezen van de

Tabel 1 Overzicht van de thema's die aan bod zijn gekomen tijdens de interviews met per thema een aantal voorbeelden van representatieve citaten

\begin{tabular}{|c|c|}
\hline Thema & Voorbeelden van citaten \\
\hline $\begin{array}{l}\text { Betrouwbaarheid en } \\
\text { meerwaarde in de } \\
\text { huisartsenpraktijk }\end{array}$ & $\begin{array}{l}\text { - "Als ik minder patiënten krijg, spring ik een gat in de lucht. De meeste urologen in Nederland werken momenteel boven hun com- } \\
\text { fortniveau. Er is te veel aanbod en een te lange wachtlijst. Ik denk dat verlichting in de werkdruk van urologen welkom is. Voor mij in } \\
\text { ieder geval wel." - U17 } \\
\text { - "Als dat een heel klein groepje is [dat je niet doorverwijst], dan is het geen waardevolle test. Als je } 1.000 \text { mannen PSA test dan en je } \\
\text { gaat dan bij } 200 \text { die test doen en je verwijst nog steeds } 180 \text { mannen door. Dan is het niet zo nuttig." - H7 } \\
\text { - "Ik denk wel dat er een beetje gewacht wordt op discriminerende tests die een onderscheid maken tussen de agressieve vormen van } \\
\text { prostaatkanker en de minder agressieve vormen van prostaatkanker. Dus dat is wel, zou echt een toevoeging zijn." - H10 } \\
\text { - "Is het verstandig om een test in een setting te gaan gebruiken waarin die niet ontwikkeld is? [... W We weten nog niet wat de testka- } \\
\text { rakteristieken zijn, wat dat in de huisartsenpopulatie doet." - H12 }\end{array}$ \\
\hline $\begin{array}{l}\text { Haalbaarheid in de } \\
\text { huisartsenpraktijk }\end{array}$ & $\begin{array}{l}\text { - "Ik vind dit eigenlijk kennis die bij de uroloog thuis hoort. Er zijn natuurlijk echt wel veel huisartsen waar dat te ver voor gaat, waar } \\
\text { het te gedetailleerd voor is. En dat is ook logisch, die kunnen niet van alle vakken alles weten. [...] Ik denk. Een verhoogd PSA bij de } \\
\text { huisarts hoort bij de uroloog. Verhoogd PSA is zo een complex stuk urologie. Prostaatkanker en verhoogd PSA, daar worden congres- } \\
\text { sen mee gevuld voor urologen. Ik kan me niet voorstellen dat de gemiddelde huisarts dat allemaal zo goed heeft zitten dat ie daar de } \\
\text { juiste beslissingen over kan nemen. Dat geloof ik gewoon niet." - U18 } \\
\text { - "Het praten over en het opsporen van prostaatkanker, dat hoort in de eerstelijn en dat gebeurt ook grotendeels in die eerstelijn. Ik } \\
\text { denk dat ik wel } 1 \text { of } 2 \text { keer per week een gesprek met mensen heb over al dan niet prostaatkanker. Dus ja, er wordt toch wel heel } \\
\text { veel in de eerstelijn over prostaatkanker gesproken." - H1 } \\
\text { - "Wil je een test goed uitvoeren, is het handig als je er routine in krijgt. Ik denk dat dit niet iets is waar je gauw routine in krijgt. Omdat } \\
\text { het een weinig voorkomende test zal zijn. In de huisartsenpraktijk. Als je er drie of vier per jaar doet, zal dat al best wel veel zijn. } \\
\text { Zeker als het om een wat kleinere praktijk gaat." - H10 }\end{array}$ \\
\hline $\begin{array}{l}\text { Draagvlak onder huis- } \\
\text { artsen en urologische } \\
\text { zorgverleners }\end{array}$ & $\begin{array}{l}\text { - "De huisartsen zien nu in hun dagelijkse praktijk. Veel dingen worden teruggeschoven naar de eerste lijn. Zo ervaren ze dat ook. Een } \\
\text { hoge werkdruk." - U1 } \\
\text { - "Een verwijzing kost ook tijd. Ik bedoel, dan moet je een verwijsbrief schrijven, daarna heb je contact met de patiënten over die ver- } \\
\text { wijzing. Op het moment dat je zegt ik doe gewoon zo'n urinetest en ik kan daarna gewoon de zaak afsluiten. Of in ieder geval een } \\
\text { nieuwe controle afspreken voor pak hem beet een half jaar of een jaar later. Dan kost dat minder tijd dan wanneer je een verwijzing } \\
\text { moet realiseren." - H2 } \\
\text { - "Nog een klein dingetje waar je je niet in moet vergissen als je dit soort dingen onder huisartsen gaat uitzetten in het huidige klimaat. } \\
\text { Dat huisartsen zich overbelast voelen. En dan zullen zij dit als een extra belasting ervaren. Dat kan best lastig zijn, om daar draagvlak } \\
\text { voor te vinden." - H11 }\end{array}$ \\
\hline
\end{tabular}


transcripten. Vervolgens zijn deze codes verfijnd door ze aan elkaar te relateren en overlappende codes te combineren. Tot slot zijn de codes gegroepeerd in overkoepelende thema's (tab. 1). Elk van deze stappen is uitgevoerd door de eerste auteur, waarbij herhaaldelijk overleg heeft plaatsgevonden met de tweede auteur om tot overeenstemming te komen.

\section{Resultaten}

De geïnterviewde urologische zorgverleners en huisartsen erkenden de mogelijke voordelen van het toepassen van moleculaire biomarkertests, zoals de SelectMDx-test, in de huisartsenpraktijk. Zij noemden een betere patiëntenselectie, minder onnodige doorverwijzingen en kosteneffectiviteit. Daarnaast benoemde een groot deel van de urologen dat zij momenteel een zeer hoge werkdruk ervaren, omdat veel mannen vanuit de huisarts doorverwezen worden met een verhoogde PSA-waarde. Volgens de urologen zou het daarom wenselijk zijn als de toepassing van moleculaire biomarkertests voor prostaatkanker in de huisartsenpraktijk bij zou kunnen dragen aan een verlaging van de werkdruk van urologen.

Naast de genoemde voordelen uitten de urologische zorgverleners en huisartsen ook verschillende twijfels en aandachtspunten voor de implementatie van moleculaire biomarkertests in de huisartsenpraktijk. Deze zijn samen te vatten als: 1) de betrouwbaarheid en meerwaarde in de huisartsenpraktijk; 2) haalbaarheid in de huisartsenpraktijk; 3) draagvlak onder huisartsen en urologische zorgverleners.

\section{Betrouwbaarheid en meerwaarde in de huisartsenpraktijk}

Zowel urologische zorgverleners als huisartsen gaven aan dat, om een weloverwogen standpunt in te kunnen nemen over de waarde van moleculaire biomarkertests voor prostaatkanker in de huisartsenpraktijk, er eerst voldoende gegevens beschikbaar moeten zijn over de betrouwbaarheid en validiteit van dit soort tests. Naar de SelectMDx-test is op dit moment bijvoorbeeld alleen nog onderzoek gedaan bij mannen die door de huisarts reeds waren doorverwezen naar de tweede lijn, maar nog niet naar de betrouwbaarheid en validiteit als deze test in de huisartsenpraktijk uitgevoerd wordt.

Ook gaven zij aan dat aangetoond moet worden of moleculaire biomarkertests voor prostaatkanker daadwerkelijk meerwaarde hebben voor de huisartsenpraktijk. Zij vroegen zich af of toepassing door huisartsen daadwerkelijk tot een significante vermindering van het aantal onnodige doorverwijzingen zou leiden zonder dat mannen met een agressieve vorm van prostaatkanker niet op tijd doorverwezen zouden worden en ook of deze tests de huisartsenzorg en de kwaliteit van leven van patiënten daadwerkelijk zouden verbeteren.
Haalbaarheid van de SelectMDx-test in de huisartsenpraktijk

Op de vraag of huisartsen de expertise in huis hebben om moleculaire biomarkertests zoals de SelectMDxtest toe te passen, was het antwoord niet eenduidig. Sommige urologische zorgverleners verwachtten dat huisartsen zo'n test prima zouden kunnen toepassen, anderen waren juist sceptisch. Zij meenden dat dit soort tests in de tweede lijn thuishoren, omdat urologen meer verstand van en ervaring met prostaatkankerzorg hebben en vroegen zich met name af of huisartsen in staat zijn om de uitslag van deze tests te interpreteren en deze te gebruiken in hun besluitvorming over doorverwijzing naar de tweede lijn.

Ook waren er twijfels over de vraag in hoeverre huisartsen in staat zijn om een goed rectaal toucher uit te voeren, wat bij veel moleculaire biomarkertests voor prostaatkanker een essentieel onderdeel is. Bij de SelectMDx-test is het rectaal toucher bijvoorbeeld noodzakelijk om prostaatkankercellen in de urine terecht te laten komen. Bovendien berust de testuitslag mede op voelbare afwijkingen in de prostaat en het inschatten van het prostaatvolume, die beide mede de testuitslag bepalen.

De meeste huisartsen die zijn geïnterviewd, waren van mening dat moleculaire biomarkertests voor prostaatkanker passen binnen het takenpakket en de verantwoordelijkheid van huisartsen, zoals het screenen op prostaatkanker, het selecteren van patiënten die doorverwezen moeten worden naar een specialist en het uitvoeren en interpreteren van diagnostische tests. Wel gaven verschillende huisartsen aan dat de haalbaarheid in de huisartsenpraktijk mede afhangt van de complexiteit van dit soort tests, die ze nu nog lastig te beoordelen vonden. Daarnaast vroegen sommige huisartsen zich af hoe moleculaire biomarkertests voor prostaatkanker ingebed zouden moeten worden in de huisartsenpraktijk. Daarbij ging het bijvoorbeeld over financiering, praktische uitvoerbaarheid en de integratie in de huidige werkwijze van huisartsen.

Om de haalbaarheid van moleculaire biomarkertests voor prostaatkanker in de huisartsenpraktijk te vergroten, meenden urologische zorgverleners en huisartsen dat het opstellen van richtlijnen voor de interpretatie van de testuitslag door huisartsen van belang is. Bij voorkeur bevatten deze richtlijnen concrete afkapwaarden waarop huisartsen zich kunnen baseren in hun besluitvorming over het al dan niet doorverwijzen naar de tweede lijn. De interpretatie van de uitslagen van moleculaire biomarkertests kan namelijk complex zijn, zoals urologische zorgverleners in ons onderzoek over de SelectMDx-test aanhaalden [10]. Daarnaast waren er twee urologen die suggereerden dat moleculaire biomarkertests toegepast zouden kunnen worden door huisartsen die zich gespecialiseerd hebben in prostaatkanker. Twee huisartsen deden de suggestie om de SelectMDx- 
test aan het huisartsenlaboratorium uit te besteden, omdat individuele huisartsenpraktijken mogelijk te weinig in aanraking komen met dergelijke tests om hier een routine in te ontwikkelen.

\section{Draagvlak onder huisartsen en urologische zorgverleners}

De meningen over het draagvlak voor het toepassen van moleculaire biomarkertests voor prostaatkanker waren verdeeld. Sommige huisartsen maakten zich geen zorgen over een mogelijke toename van werkdruk door dit soort tests, aangezien zij verwachtten dat de test weinig extra werk zou kosten. Deze huisartsen benadrukten dat het opstellen van een verwijzing ook tijd kost. Als je verwijzingen kunt besparen door dergelijke biomarkertests, bespaar je daarmee tijd. Huisartsen met een dergelijke visie verwachtten weinig problemen met het draagvlak onder huisartsen en voorspelden dat huisartsen gemotiveerd zullen zijn om een test aan te bieden waarmee je betere diagnostiek en dus betere zorg kunt leveren als huisarts. Ook verschillende urologische zorgverleners verwachtten dat huisartsen bereid zijn om moleculaire biomarkertests zoals de SelectMDx-test uit te voeren.

Er waren echter ook huisartsen en urologische zorgverleners die verwachtten dat het moeilijk zou zijn om draagvlak te creëren onder huisartsen voor moleculaire biomarkertests voor prostaatkanker, omdat huisartsen al een hoge werkdruk ervaren en er niet op zitten te wachten om nog meer taken vanuit de tweede lijn over te nemen. Zo vertelde een huisarts dat hij betrokken is geweest bij een initiatief om de nazorg voor prostaatkanker deels van de uroloog naar de huisarts te verplaatsen, waarbij hij op veel weerstand stuitte onder huisartsen.

Tot slot gaven sommige huisartsen aan dat de opinie van urologen over moleculaire biomarkertests voor prostaatkanker van belang is voor het draagvlak onder huisartsen. Als dit soort tests geen gemeengoed zijn onder urologen en niet opgenomen zijn in hun richtlijnen, is het onwaarschijnlijk dat huisartsen deze tests wel zullen omarmen. Op dit moment is er binnen de Nederlandse urologiepraktijk geen moleculaire biomarkertest voor prostaatkanker die door urologen algemeen wordt gebruikt. Er wordt met name gebruikgemaakt van de SelectMDx-test, maar dit is nog maar in een beperkt aantal ziekenhuizen het geval.

Ook gaf een aantal huisartsen aan dat het belangrijk is dat er draagvlak is onder urologen om moleculaire biomarkertests voor prostaatkanker in de huisartsenpraktijk te implementeren. Zo noemde een huisarts dat als urologen van het ziekenhuis in zijn regio achter dit idee zouden staan, hij hier zelf ook eerder voor open zou staan. Andersom kan weerstand vanuit urologen het gebruik van moleculaire biomarkertests voor prostaatkanker in de huisartsenpraktijk juist bemoeilijken.

\section{Conclusie en discussie}

In dit artikel hebben we onderzocht hoe urologische zorgverleners en huisartsen kijken naar de mogelijke implementatie van moleculaire biomarkertests voor prostaatkanker, en meer specifiek de SelectMDx-test, in de huisartsenpraktijk. Zowel urologische zorgverleners als huisartsen erkenden de mogelijke meerwaarde hiervan, zoals dat minder mannen onnodig naar de tweede lijn doorverwezen hoeven te worden. De geïnterviewde zorgverleners benoemen echter ook een aantal belangrijke aandachtspunten om te overwegen bij de eventuele implementatie van moleculaire biomarkertests voor prostaatkanker in de huisartsenpraktijk. Zo is er op dit moment nog geen wetenschappelijk onderzoek gedaan naar de validiteit en effectiviteit van deze tests in de huisartsenpraktijk. Bijvoorbeeld voor de SelectMDx-test, de biomarkertest die momenteel het meest wordt gebruikt binnen de Nederlandse urologiepraktijk, heeft het onderzoek tot nu toe alleen plaatsgevonden bij mannen die al zijn doorverwezen naar de tweede lijn [5-7]. Er zal dus eerst grondig onderzoek moeten plaatsvinden naar de betrouwbaarheid van dit soort moleculaire biomarkertests in de huisartsenpraktijk. Ook moet daarbij blijken of deze tests leiden tot een significante reductie van onnodige doorverwijzingen naar de uroloog, zonder dat agressieve vormen van prostaatkanker gemist worden.

Ons eerdere onderzoek naar het gebruik van de SelectMDx-test door urologische zorgverleners in Nederland liet zien dat de meningen van zorgverleners verdeeld zijn over wat voldoende wetenschappelijk bewijs is, bijvoorbeeld hoe groot de sample size of hoe lang de follow-up moet zijn [10]. Oftewel, zorgverleners kunnen het oneens zijn met elkaar over wat telt als voldoende bewijs. Daarom is het raadzaam om urologen en huisartsen te betrekken bij het vormgeven van wetenschappelijk onderzoek naar de betrouwbaarheid en effectiviteit van moleculaire biomarkertests voor prostaatkanker in de huisartsenpraktijk, zodat zorgverleners kunnen aangeven aan wat voor bewijs zij behoefte hebben. Dit zou bijvoorbeeld kunnen in samenspraak met urologen en huisartsen die in richtlijncommissies zitten, aangezien dergelijke commissies uiteindelijk bepalen welke innovaties in de richtlijnen komen op basis van de wetenschappelijke onderbouwing.

Het is van belang om in het achterhoofd te houden dat, ook als blijkt dat moleculaire biomarkertests voor prostaatkanker betrouwbaar en effectief zijn in de huisartsenpraktijk, dit niet automatisch betekent dat dergelijke tests snel geaccepteerd en gebruikt zullen worden door huisartsen in hun dagelijkse huisartsenpraktijk. Wetenschappelijk bewijs is geen garantie voor het verwerven van acceptatie van medische innovaties [17, 18]. Zoals ons onderzoek suggereert, moeten huisartsen nieuwe moleculaire biomarkertests voor prostaatkanker ook kunnen en wil- 
len gebruiken. Deze tests moeten passen binnen de huidige professionele waarden, verantwoordelijkheden en routines van huisartsen. Ook institutionele factoren spelen een rol, zoals de financiële vergoeding van dit soort biomarkertests. De SelectMDx-test wordt bijvoorbeeld nog niet vergoed door de zorgverzekeraar. Voor urologische zorgverleners bleek dit een belemmering te zijn voor het gebruik van deze test [10].

Daarnaast destabiliseren medische innovaties bestaande rollen, verantwoordelijkheden en expertises [19]. Moleculaire biomarkertests voor prostaatkanker die door de huisarts in plaats van door de uroloog worden uitgevoerd, leiden tot een verschuiving van de huidige taken en verantwoordelijkheden. Welke nieuwe rollen en verantwoordelijkheden ontwikkeld moeten worden, is nog onduidelijk. Uit eerder onderzoek weten we dat er in een dergelijke situatie een onderhandelingsproces op gang komt tussen verschillende betrokkenen. Zorgverleners proberen bijvoorbeeld hun bestaande expertise en identiteit af te bakenen door te betwisten welke zorgverleners de juiste kennis en vaardigheden hebben om met de nieuwe technologie om te gaan [20]. Ook kan er strijd zijn over wat de beste locatie is om een innovatie in te bedden. Dit zagen we ook terug in ons eigen onderzoek, waarbij er twijfels waren onder urologische zorgverleners of huisartsen in staat zijn om moleculaire biomarkertests toe te passen en de resultaten hiervan te gebruiken in hun besluitvorming. Kortom, hoe de uiteindelijke implementatie van een medische innovatie, zoals een moleculaire biomarkertest, eruit gaat zien is niet eenduidig. Dit hangt af van verschillende factoren, zoals de interactie en onderhandelingsprocessen tussen zorgverleners, maar ook, zoals andere studies hebben laten zien, van bijvoorbeeld de integratie van medische innovaties in professionele richtlijnen en de mogelijkheden die ziekenhuizen hebben om hun routines aan te passen [11].

Een ander belangrijk aandachtspunt is het draagvlak onder huisartsen voor de inbedding van moleculaire biomarkertests voor prostaatkanker in hun praktijk. Ook al zouden dergelijke tests de werkdruk van urologen kunnen verlagen, de werkdruk van huisartsen wordt hierdoor wellicht juist verhoogd. Huisartsen ervaren momenteel al een hoge werkdruk en het is onrealistisch om te verwachten dat huisartsen zonder meer extra taken aan hun werkzaamheden kunnen toevoegen. Ook is het maar de vraag of er draagvlak zal zijn onder urologen om moleculaire biomarkertests voor prostaatkanker te delegeren aan de huisarts.

Belangrijk om te beseffen is dat draagvlak niet te sturen is [21]. Het zal eerder een averechts effect hebben als huisartsen en urologen het gevoel hebben dat het beleid al vast staat en zij over de streep getrokken moeten worden. Om draagvlak te creëren is het van belang dat urologen en huisartsen van meet af aan worden betrokken bij het ontwikkelen van implementatie $[14,15]$. Ook tijdens het uitrollen van een imple- mentatiestrategie is het raadzaam om steeds weer pas op de plaats te maken en te onderzoeken of en hoe deze tests aan kunnen sluiten bij de actualiteit. Hiervoor zou bijvoorbeeld een werkgroep ingesteld kunnen worden bestaande uit afgevaardigden van de beroepsverenigingen voor huisartsen en urologen.

Daarnaast is onze suggestie om, parallel aan het wetenschappelijk onderzoek naar de betrouwbaarheid en effectiviteit, alvast kleinschalige pilots met moleculaire biomarkertests voor prostaatkanker, zoals de SelectMDx-test, in de huisartsenpraktijk op te zetten. Dit kan bijvoorbeeld op regionaal niveau, in samenwerking met ziekenhuizen die de SelectMDxtest al wel gebruiken en openstaan voor de optie dat huisartsen deze test gaan aanbieden.

Wij doen deze suggestie, omdat het nog onvoldoende duidelijk is hoe huidige rollen en verantwoordelijkheden gaan veranderen door de komst van moleculaire biomarkertests in de huisartsenpraktijk en wat hierbij wenselijk is. In pilotstudies zouden huisartsen kunnen oefenen met nieuwe verantwoordelijkheden, routines en samenwerking met urologen. Op deze manier kan er geïnventariseerd worden welke mogelijkheden en knelpunten er ontstaan als huisartsen moleculaire biomarkertests voor prostaatkanker toepassen. Dit kan richting geven aan het gesprek tussen huisartsen en urologen over de eventuele verdere implementatie. Hierbij is het onder meer van belang aandacht te besteden aan hoe dit soort tests in het zorgpad van prostaatkankerdiagnostiek ingebed zouden kunnen worden. Ook kan dan besproken worden welke kennis en vaardigheden huisartsen eventueel moeten aanleren of verbeteren om moleculaire biomarkertests te kunnen gebruiken, zoals inschatten van het prostaatvolume op basis van een rectaal toucher of het uitvoeren van een correcte prostaatmassage om de moleculaire biomarkers in de urine terecht te laten komen.

Tot slot, in het huidige onderzoek is een beperkt aantal huisartsen bevraagd, die bovendien doelgericht zijn benaderd, bijvoorbeeld vanwege hun bestuursfunctie of affiniteit met prostaatkanker. Ook is een significant deel van de geïnterviewde huisartsen werkzaam in de regio Nijmegen. Bij vervolgstappen in het onderzoek naar de mogelijke implementatie van moleculaire biomarkertests voor prostaatkanker in de huisartsenpraktijk raden wij aan een groter aantal huisartsen, verspreid over het land, te betrekken.

Belangenverstrengeling Ons onderzoek is gesubsidieerd door het NWO Maatschappelijk Verantwoord Innoveren onderzoeksprogramma (projectnummer 17.005). Voor deze subsidie was een in cash bijdrage van private partijen een vereiste. MDxHealth, het bedrijf achter de SelectMDx test, heeft een in cash bijdrage geleverd voor deze subsidie. MDxHealth heeft $10 \%$ bijgedragen en NWO 90\%. MDxHealth heeft geen invloed gehad op de opzet en uitvoering van ons onderzoek.

Open Access This article is distributed under the terms of the Creative Commons Attribution 4.0 International License (http://creativecommons.org/licenses/by/4.0/), which per- 
mits unrestricted use, distribution, and reproduction in any medium, provided you give appropriate credit to the original author(s) and the source, provide a link to the Creative Commons license, and indicate if changes were made.

\section{Literatuur}

1. Van Poppel H, Hogenhout R, Albers P, et al. Early Detection of prostate cancer in 2020 and beyond: facts and recommendations for the European Union and the European Commission. Eur Urol. 2020;79(3):327-9.

2. Filella X, Fernández-Galan E, Fernández Bonifacio R, Foj L. Emerging biomarkers in the diagnosis of prostate cancer. Pharmgenomics Pers Med. 2018;11:83-94.

3. Kornberg Z, Cooperberg MR, Spratt DE, Feng FY. Genomic biomarkers in prostate cancer. Transl Androl Urol. 2018;7(3):459-71.

4. AlfordAV, BritoJM, YadavKK, YadavSS, TewariAK, RenzulliJ. The use of biomarkers in prostate cancer screening and treatment. Rev Urol. 2017;19(4):221-34.

5. Hendriks RJ, Leest MMG van der, Dijkstra S, et al. A urinary biomarker-based risk score correlates with multiparametric MRI for prostate cancer detection. Prostate. 2017;77:1401-7.

6. Neste Lvan, Hendriks RJ, Dijkstra S, et al. Detection of highgrade prostate cancer using a urinary molecular biomarkerbased risk score. Eur Urol. 2016;70:740-8.

7. Haese A, Trooskens G, Steyaert S, et al. Multicenter optimization and validation of a 2-gene mRNA urine test for detection of clinically significant prostate cancer before initial prostate biopsy. J Urol. 2019;202:256-63.

8. Govers TM, Hessels D, Vlaeminck-Guillem V, et al. Costeffectiveness of SelectMDx for prostate cancer in four European countries: a comparative modeling study. Prostate Cancer Prostatic Dis. 2018;22(1):101-9.

9. Dijkstra S, Govers TM, Hendriks RJ, et al. Cost-effectiveness of a new urinary biomarker-based risk score compared to standard of care in prostate cancer diagnostics-a decision analytical model. BJU Int. 2017;120(5):659-65.

10. Wendrich K, Krabbenborg L. The adoption and use of molecular biomarker tests: an interview study with healthcare providers about a molecular biomarker test for prostate cancer. Pers Med. [Under review]

11. Greenhalgh T, Wherton J, Papoutsi C, et al. Beyond adoption:a new framework for theorizing and evaluating nonadoption, abandonment, and challenges to the scale-up, spread, and sustainability of health and care technologies. J Med Internet Res. 2017;19(11):e367.

12. Abrishami P, Boer A, Horstman K. Understanding the adoption dynamics of medical innovations: Affordances of the da Vinci robot in the Netherlands. Soc Sci Med. 2014;117:125-33.

13. Strohm L, Hehakya C, Ranschaert ER, Boon WPC, Moors EHM. Implementation of artificial intelligence (AI) applications in radiology: hindering and facilitating factors. Eur Radiol. 2020;30:5525-32.

14. Krabbenborg L. Dramatic rehearsal on the societal embedding of the lithium chip. In: van der Burg S, Swierstra T, redactie. Ethics on the laboratory floor. London: Palgrave Macmillan;2013. pag. 168-87.

15. Scheer L van der, Garcia E, Laan AL van der, Burg S van der, Boenink M. The benefits of patient involvement for translational research. Health CareAnal. 2017;25(3):225-41.

16. BoeijeH. Methoden en technieken van kwalitatieve analyse. In: Boeije H, redactie. Analyseren in kwalitatief onderzoek. Denken en doen. Den Haag: Boom Lemma Uitgevers; 2012. pag. 111-48.

17. Urquhart R, Kendell C, Geldenhuys L, et al. The role of scientific evidence in decisions to adopt complex innovations in cancer care settings: a multiple case study in Nova Scotia, Canada. Implement Sci. 201912 febr; https://doi.org/10. 1186/s13012-019-0859-5.

18. TurnerS, D'LimaD, HudsonE, Morris S, SheringhamJ, Swart $\mathrm{N}$, et al. Evidence use in decision-making on introducing innovations: a systematic scoping review with stakeholder feedback. Implement Sci. 20174 dec 12. https:// doi.org/10. 1186/s13012-017-0669-6

19. Swierstra T. Identifying the normative challenges posed by technology's 'soft' impacts. EtikkI Praksis. 2015;9(1):5-20.

20. Burri RV. Doing distinctions: boundary work and symbolic capital in radiology. Soc Stud Sci. 2008;38(1):35-62.

21. Aarts N. Voorbij het draagvlak... In: Elands BHM, TurnhoutE, redactie. Burgers, beleidennatuur: tussen draagvlak en betrokkenheid. Wageningen: Wettelijke Onderzoekstaken Natuur \& Milieu;2009. pag. 79-94.

Karine Wendrich, promovendus

Lotte Krabbenborg, universitair hoofddocent 